\title{
TEORIA CRÍTICA, FORMAÇÃO, INDIVÍDUO E PRECONCEITO: UM OLHAR SOBRE AS ESCOLAS DA REGIÃO NORTE (PA/BR)
}

\author{
Rosely Cabral Giordano \\ Universidade Federal do Pará (UFPA), Belém, Pará, Brasil \\ José LeON CROChíK \\ Universidade de São Paulo (USP), São Paulo, Brasil
}

\begin{abstract}
Resumo: O tema deste artigo - vinculado à pesquisa Educação e Políticas Públicas: exclusão social e educação inclusiva em escolas da região Norte (PA/BR), que constitui um dos subprojetos abrigados na investigação Preconceito em relação aos 'incluídos' na educação inclusiva, em curso em nível (inter) nacional - incide sobre a questão da educação inclusiva. Elegemos como problema para discussão a relação entre exclusão e inclusão social, no sentido de pensarmos - fundamentando-nos em fontes documentais, em artigos e/ou obras afins, bem como em dados empíricos já coletados - se outras formas de exclusão podem ter origem (tendência intencional ou não) nas atuais formas/conteúdos da inclusão, dada a existência do preconceito, tomado como hipótese central da referida pesquisa. Importa-nos contribuir para a formação (no sentido atribuído a esse conceito pelos frankfurtianos) dos trabalhadores da educação haja vista a importância do enfrentamento de atitudes preconceituosas no interior do processo educativo formal. Os resultados parciais da pesquisa indicam a relevância da teoria para a compreensão do objeto de que nos ocupamos, isto é, o preconceito que pode recair sobre os alunos considerados em situação de inclusão nas escolas regulares, bem como para a da leitura que sobre a educação inclusiva se tem feito.
\end{abstract}

Palavras-chave: Teoria Crítica da Sociedade. Formação. Preconceito. Educação. Educação Inclusiva. 


\section{TEORIA CRÍTICA, EDUCAÇÃO E INCLUSÃO}

Da teoria crítica à educação inclusiva: percursos teóricos

Segundo Crochík e Crochík (2008, p. 134), em virtude de a Educação Inclusiva proceder de um movimento que vem ganhando espaço após os anos 90 do século XX, não se pode retirar diretamente dessa perspectiva teórica, "[...] conceitos e princípios para se pensar a educação inclusiva". Acrescentamos que a atenção dos frankfurtianos à "[...] educação escolar não foi ampla, ainda que todos eles tenham se preocupado com a formação do indivíduo" (CROCHÍK; CROCHÍK, 2008, p. 134) e que, dentre eles, quem mais se destacou no estudo dessa área foi TheodorW. Adorno, principalmente na década de 1960. Acrescentaríamos, ainda, ao referido pelos autores acima indicados, que a dificuldade de estabelecermos um liame entre a Educação e os conceitos advindos da Teoria Crítica pode vir a ser superada por um dos elementos teóricos fundamentais da obra dos frankfurtianos, particularmente, da de Adorno e Horkheimer: o retorno à empiria, que nos auxilia a pensar o objeto por nós delimitado para estudo, i. é, o da educação inclusiva e, no interior desta, o do preconceito que pode recair sobre os alunos em situação de inclusão nas escolas regulares.

Assim, ao posicionarmo-nos, adentramos o equacionamento conferido por Adorno a um dos pares de opostos mais relevantes da Teoria do Conhecimento: o da relação que envolve aparência e essência a qual, a seu turno, nos remete à crítica adorniana ao positivismo. Uma e outra questão serão abordadas nos momentos em que, ao longo deste artigo, fazemos referência às questões de método orientadoras da pesquisa que conduzimos. Dentre as questões a que nos referimos, elegemos duas que consideramos fundamentais haja vista serem afetas ao nosso objeto de investigação, a saber: (a) da relação entre teoria e empiria e (b) a da leitura que sobre a educação inclusiva se tem feito.

\section{Em torno de questões teórico-metodológicas}

Não somente a teoria como também sua ausência se converte em força material quando se apodera das massas. A pesquisa social empírica não é corretiva apenas ao impedir construções cegas a partir de cima, mas também 
no tocante à relação entre essência e aparência. Se cabe à teoria da sociedade relativizar criticamente o valor de conhecimento da aparência, então à pesquisa empírica, por seu turno, cabe proteger a essência da sua mitificação. A aparência é sempre uma manifestação da essência e não mera ilusão. Suas mudanças não são indiferentes para a essência. Quando de fato ninguém mais sabe que é trabalhador, isso afeta a composição interna do conceito correspondente, ainda que a sua definição objetiva - aquela baseada na separação dos meios de produção - se mantenha plena. (ADORNO apud COHN, 2008, p. 24, grifo nosso).

Da citação eleita para dar início à polêmica subsumida nesta questão partimos da expressão decisões metodológicas que, para Adorno, pede por certo refinamento, pois implica temas relativos à própria Filosofia. Dito de outro modo, decidir sobre método/metodologias requer pensar a teoria (ou sua ausência) devido à mesma ser parte intrínseca da pesquisa social empírica e esta, a seu turno, das relações entre essência e aparência. Exemplo desta relação manifesta-se, particularmente, na língua, isto é, no também par de opostos representado pela palavra e pelo objeto por ela designado. A língua - enquanto manifestação histórica e concreta da linguagem - transforma-se de modo a poder acompanhar as mudanças sócio-históricas no interior das quais se encontra o objeto' ${ }^{1}$ A cesura à qual nos remetemos (oposição entre palavra e objeto e, portanto, entre a língua e a própria realidade) refere-se à obra Dialética do Esclarecimento, em particular, ao fragmento A indústria cultural: o esclarecimento como mistificação das massas, em que Horkheimer e Adorno (1985) elucidam-nos acerca da ruptura entre o signo e seu conteúdo, unidade presentificada nos mitos. Lemos, em Horkheimer e Adorno (1985, p. 153), que a palavra e o conteúdo por ela designado, embora distintos, são inseparáveis, tendo estado - no passado mítico - associados um ao outro. No entanto, afirmam os autores:

[...] quanto mais as palavras se convertem de veículos substanciais do significado em signos destituídos de qualidade, quanto maior a pureza e a transparência com que transmitem o que se quer dizer, mais impenetráveis elas se tornam. A desmitologização da linguagem, enquanto elemento do processo total de esclarecimento, é uma recaída na magia [...]. Conceitos como melancolia, história e mesmo vida, eram reconhecidos na palavra que os destacava e conservava. (HORKHEIMER; ADORNO, 1985, p. 153). 
Se, portanto, a linguagem encontra-se, após essa separação, adaptada ao que está morto ${ }^{2}$ - tão sem vida quanto é próprio do pensar burguês - isto torna a palavra purificada do que nela encontrava-se assimilado, sendo, pois, fundamental restituir à palavra a experiência ${ }^{3}$ enquanto mediação para os que consideram a possibilidade de a ciência auxiliar a compreensão da atualidade, compreensão que se explica em virtude de, para os autores, a crítica do conhecimento constituir, simultaneamente, crítica do social. Tal ilação é clara na passagem a seguir:

Os observadores tiveram de superar a repulsa pela atitude objetiva de espectadores desinteressados, com que deviam realizar as observações e o estudo desse horror que custou a vida de muitos milhões de vítimas inocentes. A essa atitude de investigação poderia ser acrescentada a convicção de que o conhecimento sociológico-científico, em sua particularização e com suas tonalidades, oferece alguma possibilidade de impedir, eficazmente, a repetição da calamidade onde ela surgir como ameaça e sejam quais forem as vítimas designadas. Além disso, quem deseja oferecer a ajuda da ciência na sociedade atual, deve usar tais métodos, alheados do imediatamente humano, entrincheirados atrás dos grandes números, das leis estatísticas, dos questionários e dos testes, entre outros símbolos semelhantes de desumanização. Mas este paradoxo não pode ser evitado, melhor dizendo, é necessário reconhecê-lo e reconhecê-lo na prática. (HORKHEIMER; ADORNO, 1978$, p. $172-3)^{4}$.

Reside aí - na utilização de métodos que (consignados pelo positivismo) simbolizam a alheação do processo de desumanização - o que denominamos restituir à palavra a experiência ou, na expressão de Horkheimer e Adorno, trazer o objeto à experiência, acercando-nos do mesmo por meio da pesquisa empírica haja vista o imperativo de superarmos a produção de uma ordem científica unitária, bem como o derivar o conhecimento dos fatos a partir de princípios. Tal atitude é propícia à busca da essência dos fatos desde a sua aparência e/ou à compreensão da totalidade partindo da menor parte, daquela, inclusive, em que, no mais das vezes, não parece estar contida a essência do objeto que se busca. Auxiliam-nos as palavras de Horkheimer e Adorno (1985, p. 81):

O aspecto 'sistemático' do conhecimento consiste na 'conexão dos conhecimentos a partir de um princípio'. O pensamento, no sentido do escla- 
recimento, é a produção de uma ordem científica unitária e a derivação do conhecimento factual a partir de princípios, não importa se estes são interpretados como axiomas arbitrariamente escolhidos, ideias inatas ou abstrações supremas. As leis lógicas estabelecem as relações mais gerais no interior da ordem, elas as definem. A unidade reside na concordância. [...]. A verdadeira natureza do esquematismo, que consiste em harmonizar exteriormente o universal e o particular, o conceito e a instância singular, acaba por se revelar na ciência atual como o interesse da sociedade industrial.

Subtrair o conceito da natureza do esquematismo, interrompendo essa harmonização exterior entre o universal e o particular - ambos socialmente mediados -implica esse giro em direção à experiência. Assim, ao buscarmos a essência de um objeto, na perspectiva de superarmos o positivismo ${ }^{5}$ - que, de forma alguma, dela se ocupava - afirmaríamos a necessidade da interpretação do significado de um objeto em seu contexto, destacando sua importância relativamente ao sujeito, na tentativa de reverter o processo que constitui o fundamento do estreitamento da experiência significativa para o sujeito (formação). Para isso, além do contexto, o movimento contínuo da história, que se nomeia progresso, com todas suas contradições, deve ser considerado tendo em vista o'sopro' do passado que dá sentido à experiência universal e permite a experiência individual em sua articulação com a coletiva. Assim, o movimento do esclarecimento deve simultaneamente voltar-se à delimitação do contexto que dá sentido à experiência e à sua expansão que retira o contexto de seu isolamento, tornando-o universal. A aparência que se modifica ao longo do tempo, segundo Adorno (apud COHN, 2008, p. 24), também revela a alteração da essência, assim, os estudos 'epidérmicos' dos fenômenos sociais - atitudes, opiniões, representações sociais - permitem uma'porta de entrada'ao'eu que acompanha todas as minhas representações', que não é diretamente visível e do qual restam dúvidas, na atualidade, de sua existência, dado o esquematismo que substitui a experiência, tal como indicado anteriormente.

\section{Descrição dos instrumentos da pesquisa e seus objetivos}

Afirmamos acima a importância da utilização de métodos que, além de expressar o processo de alheação do humano, podem contribuir para, na 
expressão de Horkheimer e Adorno, trazer o objeto à experiência, permitindo-nos acercá-lo por meio da pesquisa social empírica. Segundo Adorno et al. (1965), não são somente os métodos que são alheios ao que deveria ser humano, mas o próprio indivíduo que regrediu face ao que pode ser, apesar de sofrimentos que experimentou na época do capitalismo concorrencial. Desse modo, além de nos indignarmos com a frieza existente nos métodos que tratam o indivíduo como um objeto sem vida própria, devemos também criticar as condições que o tornaram assim.

O estudo da aparência, nesse sentido, busca quer o que é substancial no objeto ou a ausência dessa substância; em ambos os casos, trata-se da luta política de reaver um objeto perdido, quer esse objeto seja o indivíduo, uma instituição social, ou a cultura. Se os instrumentos devem se adaptar ao objeto, assumir sua forma, operar a mimesis, para melhor investigá-lo, a um objeto'regredido' devem ser adequados àqueles que - ao descrevê-lo como está podendo ser - tragam a possibilidade de o objeto ser de outra forma que negue a atual aparência estudada.

Nessa perspectiva expomos os resultados de dois dos instrumentos aplicados e dados parcialmente coligidos por meio das entrevistas semiestruturadas e das observações realizadas na escola ${ }^{6}$.

Demos início à pesquisa aplicando seus dois primeiros instrumentos: Formulário para caracterização de escolas e o Questionário para os Diretores e/ou Coordenadores Pedagógicos ${ }^{7}$, cujo objetivo é caracterizar a escola selecionada segundo o seu grau de inclusão. Passamos, em seguida, à entrevista com os professores da $4^{a}$. série ( $5^{\circ}$ ano) do ensino fundamental, constituída por um roteiro de questões semiestruturadas, dado termos considerado esta ser suficientemente flexível no sentido de permitir a inclusão ou subtração de questões não pensadas anteriormente, dependendo da resposta do entrevistado. Seus objetivos são: (a) verificar sua concepção de educação inclusiva e sua atuação junto aos seus alunos em situação de inclusão e (b) conhecer suas expectativas quanto a esses alunos. Simultaneamente à realização da entrevista com as docentes dessa série, estamos cumprindo a etapa das observações em sala de aula as quais temos realizado ao longo de, pelo menos, um semestre letivo. Para a utilização deste instrumento seguimos um roteiro 
- utilizado por todos os pesquisadores que participam da investigação - que focaliza nossa atenção no comportamento dos alunos em situação de inclusão e na interação dos mesmos com os professores e os demais colegas da sala de aula em observação. A importância desse instrumento reside na possibilidade de verificar se os alunos em situação de inclusão são incluídos nas atividades escolares ou se são segregados, marginalizados.

\section{EDUCAÇÃO E INCLUSÃO: COMO TUDO COMEÇOU}

\section{A inclusão escolar nos documentos oficiais}

A escolarização das crianças consideradas em situação de inclusão (S. de I. $)^{8}$ nas escolas regulares encontra sua contextualização no seio das políticas públicas e das práticas socioescolares derivando-se da popularização da temática da inclusão social ocorrida desde o final dos anos 80 e, mais fortemente, a partir do início da década de 1990. Não por acaso, esse é também o momento histórico em que têm lugar as mutações ocorridas no mundo do trabalho as quais deram origem à nova ordem mundial que, internacionalizando a economia, gestou a política neoliberal ${ }^{9}$ cuja característica básica é ingerir maximamente, por meio do aparelho de um Estado mínimo, na política socioeconômica. O Estado deixa de produzir as condições de infraestrutura da produção, para as quais se associa com a iniciativa privada ou entrega diretamente ao setor privado a sua realização e, de outro lado, amplia os controles de vigilância e punição ao que pode obstar o bom andamento do sistema. Tal é, por excelência, a função do Estado na condição de encarregado da garantia dos interesses da classe social interessada nesse conjunto de modificações. No bojo desse processo político-econômico e, ainda, sob a pressão dos movimentos da sociedade civil organizada - ainda não completamente esfacelada pelo neoliberalismo ${ }^{10}$ - é que ganha maior espaço político o movimento mundial em favor da inclusão, fundamentalmente expresso em três documentos internacionais: (1) Convenção sobre os Direitos da Criança, de novembro de 1989'1'; (2) Conferência Mundial sobre Educação para Todos, realizada em Jomtien (Tailândia), em março de 1990 e (3) Declaração de Salamanca (Conferência Mundial de Educação Especial) que, 
ocorrida no município espanhol de Salamanca, em junho de 1994, reafirma o compromisso para com a proposição "Educação para Todos".

A Convenção sobre os Direitos da Criança - recordando que na Declaração Universal dos Direitos Humanos ${ }^{12}$ as Nações Unidas proclamaram que a infância tem direito a cuidados e assistência especiais - afirma, no Artigo $28^{\circ}$ (§ 1), que os Estados Membros reconhecem o direito da criança à educação, a fim de que ela possa exercer progressivamente, em igualdade de condições, esse direito. Para tanto, os Estados Membros devem tornar o ensino primário obrigatório e disponível a todos, gratuitamente, reconhecendo (1) que as crianças com deficiência(s) física(s) ou mental deverão desfrutar de uma vida plena e decente em condições dignas, garantindo sua autonomia e facilitando sua participação ativa na comunidade e (2) os direitos que estas têm de receber um atendimento especial, estimulando e assegurando a prestação de serviços adequados, conforme a situação da criança e as circunstâncias de seus pais ou responsáveis.

Menos de um ano decorrido após a proclamação da Convenção sobre os Direitos da Criança é apresentada a Declaração Mundial sobre Educação para Todos (UNESCO, 2011) reafirmando a Declaração Universal dos Direitos Humanos para denunciar que - apesar dos esforços realizados no sentido de afirmar o direito de todos à educação - perduram as desigualdades em relação ao referido direito, bem como àquelas referentes aos gêneros ${ }^{13}$.

Se, entretanto, pensamos/propomos o direito jurídico de todas as crianças e adultos à educação, em que pesem os limites dessa proposição em meio a uma sociedade fundada na desigualdade entre pessoas de diferentes níveis socioeconômicos ${ }^{14}$, evidencia-se, mesmo no interior desse contexto, a exclusão de grande parte dessas crianças e adultos, é dizer, daqueles em situação de inclusão, anteriormente designados como portadores de deficiências ou de necessidades especiais. Com o propósito de combater essa exclusão, é realizada a Conferência Mundial de Educação Especial, Declaração de Salamanca que, conforme acima exposto, partindo da reafirmação do compromisso para com a proposição da Educação para Todos, propõe o alargamento de tal compromisso por meio da adoção de sistemas mais flexíveis e adaptativos, que levem em consideração as diferentes necessidades das crianças o que irá 
contribuir simultaneamente para o sucesso educacional e para a inclusão. Não se trata, portanto, de apresentar uma proposta que atinja apenas a inclusão de crianças com necessidades educacionais especiais:

\begin{abstract}
Muitas das mudanças requeridas não se relacionam exclusivamente à inclusão de crianças com necessidades educacionais especiais. Elas fazem parte de uma reforma mais ampla da educação, necessária para o aprimoramento da qualidade e relevância da educação, e para a promoção de níveis de rendimento escolar superiores por parte de todos os estudantes. A Declaração Mundial sobre Educação para Todos enfatizou a necessidade de uma abordagem centrada na criança objetivando a garantia de uma escolarização bem-sucedida para todas as crianças. A adoção de sistemas mais flexíveis e adaptativos, capazes de mais largamente levar em consideração as diferentes necessidades das crianças irá contribuir tanto para o sucesso educacional quanto para a inclusão. (BRASIL, 2009).
\end{abstract}

Quase duas décadas são decorridas após a Declaração de Salamanca. Relativamente ao tempo decorrido, é possível afirmarmos avanços concernentes à inclusão escolar dessas crianças, haja vista que, no Brasil, em 2003, de um total de 504.039 crianças consideradas em S. de I. que frequentavam escolas (escolas exclusivas e classes especiais e/ou regulares), apenas 145.141 (28,79\%) estavam matriculadas em escolas regulares; já em 2006, de 700.624 crianças consideradas em S. de l., o número de matrículas nas escolas regulares passou a 325.136 (46,40\%). Em 2008, de 695.699 crianças, 375.775 (54,01\%) passaram a frequentar escolas regulares. Esses números indicam que, entre 2003 e 2008, o número de matrículas de crianças consideradas em S. de I. nas escolas regulares cresceu na ordem de 230.634 , isto é, 62,93\%. Lemos, ainda, no documento Resumo Técnico - Censo Escolar 2010, publicado pelo MEC/INEP (2011) dados mais recentes, indicando que no ano de 2010 houve um aumento de $10 \%$ no número de matrículas da Educação Especial. Em 2009, eram 639.718 matrículas e, em 2010, passaram a 702.603. Segundo o mesmo documento:

Os importantes avanços alcançados pela atual política são refletidos em números: $62,7 \%$ do total de matrículas da educação especial em 2007 estavam nas escolas públicas e 37,3\% nas escolas privadas. Em 2010, estes números alcançaram $75,8 \%$ nas públicas e $24,2 \%$ nas escolas privadas, mostrando claramente a efetivação da educação inclusiva e o empenho das redes de 
ensino em envidar esforços para organizar uma política pública universal e acessível às pessoas com deficiência (MEC/INEP, 2011).

Para além dos documentos acima enunciados, também em nível nacional, dispomos de dispositivos legais, indicando que o Brasil seguiu o movimento ocorrido mundialmente relativamente à proposição educação para todos. Exemplos significativos dessa adesão à inclusão escolar, apresentados em ordem cronológica, são: (a) a Constituição da República Federativa do Brasil de 1988; (b) Lei 7.853, de 1989, que dispõe sobre o apoio às pessoas portadoras de deficiência, sua integração social; (c) o Estatuto da Criança e do Adolescente (ECA), de 1990, que reforça a obrigação de os pais ou responsáveis matricularem seus filhos na rede regular de ensino e (d) a Lei n 9.394/96, Lei de Diretrizes e Bases da Educação Nacional (LDBEN).

Poderíamos afirmar que grande parte da história de como tudo começou passa pela relação entre educação e inclusão, tal como indicado pelos documentos oficiais e obras referidas é simultânea às políticas neoliberais relativamente às políticas concernentes à Educação, Cultura e Saúde. Cumpre ressaltar que muito embora não possamos desconsiderar a força dos movimentos sociais em defesa da inclusão, parece não haver dúvidas quanto à intervenção dos organismos internacionais (particularmente, a do Banco Mundial) na exigência do cumprimento das políticas públicas educacionais pelos países clientes dos referidos organismos. Ocupados com o desafio da inclusão, afirma Wolfensohn (1997, p. 6):

Our goal must be to reduce these disparities across and within countries, to bring more and more people into the economic mainstream, to promote equitable access to the benefits of development regardless of nationality, race, or gender. This - the Challenge of Inclusion - is the key development challenge of our time. ${ }^{20}$

Nas palavras de Patto (2000, p. 194):

20 Nosso objetivo deve ser o de reduzir essas disparidades entre e no interior dos países para trazer mais e mais pessoas para o desenvolvimento econômico principal, promover o acesso equitativo aos benefícios do desenvolvimento, independentemente da nacionalidade, raça ou sexo. Este - o desafio da inclusão - é a chave para o desenvolvimento quanto ao principal desafio do nosso tempo. (Tradução nossa). 
É sabido que a política atual caracteriza-se por tentativas de internalização dos expulsos, seja pela criação de uma rede de caminhos dentro da escola de primeiro grau - os quais, sob o pretexto de incluir, prolongam a ilusão da inclusão, pois, mesmo que os percorram, esses alunos não tiveram acesso a um ensino que se possa dizer de boa qualidade -, seja pelo afrouxamento dos critérios de avaliação de aprendizagem, com intenção clara, mas não confessada, de empurrar de qualquer jeito os estudantes de baixa renda pelos graus escolares adentro, quando possível até o terceiro grau.

Ambas as citações, como que espelhadas, põem em questão a educação inclusiva, como coroamento da dissimulação dessa ideologia recente. Outra hipótese distinta é: o avanço das forças produtivas talvez tenha acarretado o mesmo efeito indicado por Marx (1984) do maquinário sobre a possibilidade de as mulheres, jovens e crianças trabalharem; com esse avanço, passa a ser possível a admissão de pessoas sem competências que antes eram fundamentais para o trabalho. Outra hipótese ainda refere-se ao fenômeno do desemprego estrutural, que diminuindo significativamente o número de empregos necessários para a produção social pode desvincular a escola do trabalho, reduzindo sua função de formar para o trabalho; os que anteriormente causariam prejuízos na esfera da produção, desse modo, poderiam ser incorporados na esfera da cultura.

Qualquer uma dessas duas hipóteses se refere às forças produtivas que, sem dúvidas, não devem ser consideradas sem a ação das relações de produção, mas permitem pensar as contradições sociais que as citações de Wolfensohn e Patto parecem não contemplar. Se, de acordo com Horkheimer e Adorno (1985), o esclarecimento tem um movimento dialético, ele não pode ser somente regressivo. Poder ter direito à educação é um avanço social; entretanto se esta ainda é de qualidade duvidosa, cabe criticá-la para que seja efetivamente voltada à vida e não apenas à adaptação relativamente às miseráveis condições existentes: se a escola exclui ao incluir, está respondendo a um fenômeno mais amplo; mas, se ela também inclui os que antes não poderiam nela estar presentes, amplia a possibilidade de identificação entre alunos diferençados entre si, e, assim, também a identificação com o mais frágil que permite a educação escolar ir além da adaptação social; a escola também pode permitir ir além da vida imediata: por mais que se diga, aliás 
corretamente, que parte importante da educação escolar esteja voltada à adequação ao mundo do trabalho, ainda que isso seja anacrônico, parece não ser menos verdadeira a possibilidade do'muro escolar' dificultar a adesão imediata, devido a esses mesmos 'muros'.

\section{In(ex)clusão e preconceito socioescolar}

La inclusión en educación implica desarrollar procesos para aumentar la participación y reducir la exclusión de los/as estudiantes, esto implicará reestructurar la cultura y las prácticas de los centros educativos para que puedan atender la diversidad del alumnado de su localidad [...]. Equidad no es sólo igualdad de acceso, sino también, de derechos a recibir una educación que desarrolle al máximo las potencialidades de los/las estudiantes, fenómeno que se ha verificado en situación de riesgo especialmente en contextos educativos de alta vulnerabilidad y concentración étnica (Becerra, Tapia, Mansilla, 2009). A la vista de las consideraciones anteriores, la tarea es construir un sistema cada vez más inclusivo, cuyo objetivo sea intentar frenar y cambiar la orientación de una sociedad en que los procesos de exclusión social son cada vez más fuertes, y por esta razón empujan a un número mayor de estudiantes a vivir su vida por debajo de los niveles de dignidad e igualdad al que todos tenemos derecho [...]. (ORREGO et al., 2012, p. 166). ${ }^{21}$

Apesar de as autoras referirem-se ao preconceito étnico (questão também levantada pelo segundo instrumento da pesquisa), auxiliam-nos ao afirmarem um horizonte comum ao que defendemos para a sociedade e escolas. Auxiliam clarificando que é nossa a tarefa de construir um sistema social crescentemente inclusivo, objetivando frear e modificar a orientação de uma sociedade [aquela fundada na propriedade privada] em que os processos de exclusão social são cada vez mais fortes o que impele um número cada vez maior de estudantes [em se tratando da escola] a viver abaixo do nível de dignidade e igualdade ao qual todos temos direito, pois um dos

21 A inclusão na educação implica desenvolver processos para aumentar a participação e reduzir a exclusão dos / das estudantes, o que implicará a reestruturação da cultura e práticas das escolas para que possam atender à diversidade de alunos de sua localidade [...]. Equidade não é apenas a igualdade de acesso, mas também o direito a uma educação que desenvolva ao máximo as potencialidades dos estudantes, fenômeno verificado em situação de risco, especialmente, em contextos educativos de alta vulnerabilidade e concentração étnica (Becerra Tapia, Mansilla, 2009). Tendo em vista as considerações anteriores, a tarefa é construir um sistema cada vez mais inclusivo, cujo objetivo seja enfrentar, frear e transformar a orientação de uma sociedade em que os processos de exclusão social são cada vez mais fortes, os quais, por esta razão, impelem um maior número de estudantes a viver suas vidas abaixo dos níveis de dignidade e igualdade a que todos temos direito. (Tradução nossa). 
direitos básicos de todo indivíduo seria o de ter condições dignas de vida e, consequentemente, de Educação.

É Martins (1997, p. 22) quem primeiro nos propicia responder à questão da precariedade da inclusão: "Estamos em face de uma nova desigualdade, e não mais apenas da desigualdade gerada pelo aparecimento das classes sociais".

Nesse sentido, não se pode pensar tal inclusão como sendo fruto, exclusivamente, do surgimento das classes sociais, dado o surgimento das mesmas ter estado, quase sempre, ligado a atos de protestos. Ainda segundo Martins (1997, p. 22), as classes sociais "[...] foram ou são revolucionárias". Portanto, a presença da precariedade e mesmo da perversidade da exclusão deve-se, em uma primeira instância, à onipotência do Capital, que amputa nossos desejos de mudança, transformando-nos em consumidores e, também, no seio das relações sociais de produção, em produtos substituíveis até que vença o prazo de validade determinado.

O modelo da inclusão educacional representa, entretanto, um avanço significativo em relação ao da educação especial, pois tem como princípio uma educação comum a todos, no sentido de permitir que as oportunidades dos alunos de classes regulares sejam as mesmas para os alunos considerados em situação de inclusão. Acredita-se em uma educação inclusiva na qual as crianças sejam - e não só por direito jurídico - incluídas, sem que as diferentes faces do preconceito recaiam sobre as mesmas ou mesmo o alheamento em relação às suas manifestações, haja vista diferentes segmentos sociais cobrarem da escola atitudes concretas relativamente à superação destas. A escola, por sua vez, não tem respondido de maneira plausível às atitudes preconceituosas às quais são submetidos os alunos, deixando assim, um ar de desconfiança e descrédito por parte de familiares. Na perspectiva da educação para todos deve-se pensar em dar oportunidades e criar formas de incluir todos os alunos, sem deixar à margem aquele que não corresponde ao modelo que, muitas vezes, é desejado pela escola. Relembramos que:

O Estado, ao conceber as políticas de educação, as projetou para os alunos aos quais era atribuída a identidade de normais, excluindo, nesse processo, os alunos identificados como anormais. Coube a movimentos sociais e 
comunitários organizarem-se com vistas a suprir a carência de serviços do Estado voltados à educação dessas pessoas (MACHADO e PAN, 2012, p. 279).

Ao falarmos em inclusão pensamos em todos aqueles que se encontram incluídos em uma sociedade que segrega e exclui cada vez mais os indivíduos. Isso se dá por meio das relações existentes nos espaços escolares e nos demais ambientes em que os alunos estão inseridos, pois apenas matricular um aluno em uma escola regular não implica a convivência, na igualdade, com os demais - diferentes de si. Inclusão é conviver na e com a diferença. Considerar, pois, que na escola não há exclusão ou que ela precisa de sérios reparos constitui uma visão romântica e ideológica da escola e da própria sociedade. Na verdade, as várias formas de preconceito - geradoras da exclusão das pessoas que não se encaixam nos padrões sociais naturalizados e normalizados - convivem no cenário escolar.

Segundo Crochík (1997), o preconceito resulta do processo de socialização, sofrendo, portanto, alterações ao longo do tempo em função das diferenças culturais e dos condicionantes históricos. A sociedade, por sua vez, exige um crescente processo de adaptação ao real face à necessidade de lutarmos, cotidianamente, pela sobrevivência. Desse modo, ainda segundo o autor, o preconceito surge como resposta aos conflitos presentes nessa luta, não estando ligado apenas ao indivíduo que é vitima do preconceito, mas, também, ao sujeito preconceituoso, como reflexo de toda uma conjuntura social. Antes, o preconceito tem profunda relação com as necessidades que se encontram no sujeito preconceituoso. Nesse sentido, Crochík (1997) indica a necessidade de repensarmos o processo de formação, pois, quanto maior a dificuldade do sujeito em experimentar e refletir sobre o objeto ou sobre o próprio real maior será sua necessidade de defesa frente aos objetos que Ihe causam estranheza. Podemos dizer que o preconceito é o sentimento de medo ante o diferente, o desconhecido. Nas palavras do autor: "[...] o medo frente ao desconhecido, ao diferente, é menos produto daquilo que não conhecemos, do que daquilo que não queremos e não podemos reconhecer em nós mesmos através dos outros". (CROCHÍK, 1997, p. 14)

Nesse mesmo contexto, Crochík afirma que a forma mais característica de o sujeito relacionar-se com a sociedade é por meio do estereótipo, 
entendendo-o como um elemento do preconceito. O estereótipo é produto de nossa cultura que se relaciona com mecanismos psíquicos infantis, quando do seu processo de diferenciação com o mundo externo. Sob a égide do preconceito está o movimento de exclusão/inclusão de grupos minoritários que, por longos períodos, lutaram e lutam por visibilidade nos grupos sociais, não só para serem aceitos, mas, principalmente, para serem respeitados como qualquer outro cidadão:

O preconceito diz respeito a um mecanismo desenvolvido pelo indivíduo para poder se defender de ameaças imaginárias, e assim é um falseamento da realidade, que o indivíduo foi impedido de enxergar e que contém elementos que ele gostaria de ter para si, mas se vê obrigado a não ter; quanto maior o desejo de poder se identificar com a pessoa vítima do preconceito, mais esse tem de ser fortalecido (CROCHíK, 2006, p. 22).

Destacamos, ainda, que"Se a sociedade se alterou em sua base econômica, por meio da concentração do capital, as diversas instâncias sociais também se modificaram. Dentre elas, destacam-se duas: a família e a escola" (CROCHÍK, 2008, p. 82).

Esse processo de mudança e crise na família é sentido na contemporaneidade: os filhos passaram a ter uma educação voltada ao mercado de trabalho e a atenção em relação à formação do indivíduo passou a ser compartilhada, se não demasiadamente, com outras instituições, o que teve consequências "[...] no enfraquecimento da autoridade familiar" (CROCHÍK, 2008, p. 83) ao ponto de o mesmo não saber qual a direção a seguir. A substituição da educação familiar em conformidade com outras instituições constitui uma prática da educação voltada imediatamente aos interesses do capital. De acordo com Crochík (2006, p. 142), a família também deveria ser responsável pela socialização do indivíduo, pela sua "[...] preparação para o mundo do trabalho e deveria funcionar como elemento mediador entre sociedade e o individuo". Em virtude de a mediação e a socialização da criança terem sido incorporadas por outras organizações, levanta-se a questão dos valores familiares serem esquecidos:

Os especialistas dos meios de comunicação com a massa transmitem os valores requeridos; oferecem o treino perfeito em eficiência, dureza, perso- 
nalidade, sonho e romance. Com essa educação, a família deixou de estar em condições de competir. Na luta entre as gerações, os lados parecem ter sido trocados: o filho é quem sabe; é ele quem representa o princípio maduro de realidade contra as obsoletas formas preconizadas pelo pai. (MARCUSE, 1981, p. 97).

As consequências de tais valores alienantes transformam-se em reprodução daquilo que a cultura social, ante os meios de comunicação de massa, tenta substituir por outros valores (familiares) essenciais à formação do indivíduo. Diante disso "[...] a autoridade familiar, assim como a do professor" (CROCHÍK, 2006, p. 143) que antes tinha um sentido, agora vive aquém. Embora tentemos compreender/combater o preconceito, não são poucos os movimentos em contrário, sugerindo a exclusão de algum grupo minoritário, movimentos que não têm ocorrido isoladamente. Em meio às buscas e lutas no sentido de compreender/combater o preconceito, vivemos as (in) certezas de que tais processos de inclusão - como propostos pelas políticas públicas em documentos nacionais e internacionais - possam ser alcançados de modo a minimizar a exclusão escolar, fator histórico na formação social brasileira, pois, como afirma Feltrin (2007, p. 15) “[...] a sociedade e a escola, mais os professores na sala de aula, devem estar preparados e capacitados para poder tratar e conviver com a diferença".

DOS ACHADOS DA PESQUISA

Instrumentos aplicados

A Escola Alpha ${ }^{16}$ - onde atualmente estamos realizando a pesquisa - é uma escola da rede pública de ensino em Belém (PA), que disponibiliza o Ensino Fundamental e Médio (modalidade Educação de Jovens e Adultos). Relativamente ao modelo inclusivo de educação, a escola é considerada como referência pela SEDUC. A escolha desta escola para a realização da pesquisa empírico-social deve-se, pois, à estimativa deste alto grau de inclusão. A escola funciona nos três períodos (manhã, tarde e noite), tendo, em 2012, 664 alunos matriculados. No concernente à aplicação dos instrumentos da pesquisa, já foram aplicados os dois primeiros instrumentos (Formulário para caracterização de escolas e o Questionário para os Diretores e/ou Coordenadores 
Pedagógicos) e iniciadas as observações em sala de aula que terão duração de um semestre letivo e meio. Objetivando obter informações não contidas na primeira entrevista (parte do Questionário para os Diretores e/ou Coordenadores Pedagógicos), realizada com a Vice-Diretora da escola, professora Solange, decidimos realizar nova entrevista com o Coordenador Pedagógico, também professor, acrescentando questões ${ }^{17}$ a este segundo instrumento que esclarecessem pontos não elucidados na entrevista realizada com a Vice-Diretora.

Descrição e análise dos dados

Sobre a escola e a inclusão

a partir das discussões acerca da educação inclusiva realizadas nas últimas décadas, a legislação de diversos países foi alterada, possibilitando o ensino regular para crianças e adolescentes que antes frequentavam escolas ou classes especiais ou mesmo não iam à escola. Para se adequar aos alunos em situação de inclusão, as escolas reformularam o ambiente físico, o currículo e a avaliação (CROCHÍK et al., 2011, p. 72).

Ena Escola Alpha, o que mudou em virtude da alteração da legislação?! Após a aplicação do Formulário para caracterização de escolas constatamos que dentre os 664 alunos matriculados na escola, 26 deles são considerados alunos em S. de I. O universo de alunos da escola está distribuído em 26 salas de aula. Ainda que a escola tenha 39 professores, a média de alunos por professor não se altera, na medida em que, em algumas salas (dependendo do nível de ensino e/ou série) há mais de um professor por sala. A proporção de alunos por sala corresponde, portanto, a 25,54, número que se encontra em conformidade com o requerido no Documento Base da Conferência Nacional da Educação (BRASIL, 2012, p. 97). Lemos no referido documento a proporção de alunos por professor para os diferentes níveis do ensino: "[...] no ensino fundamental: nos anos iniciais, 25 alunos/as por professor/a; nos anos finais, 30 alunos/as por professor/a; (3) no ensino médio e na educação superior, até 35 alunos/as por professor/a".

Contrariamente, a proporção de alunos considerados em S. I. (3,9\%) em relação ao universo de alunos da escola (664) pode ser considerada bastante baixa para uma escola tida como sendo referência quanto à inclusão. 
A escola dispõe de uma sala multifuncional (S. M.) para os alunos considerados em $\mathrm{S}$. de I. que são atendidos por três professores. Cada aluno considerado em situação de inclusão tem um horário específico para ser atendido. No horário determinado para seu atendimento, o aluno se ausenta da sala de aula regular indo para a S. M., onde são trabalhadas suas dificuldades, prioritariamente, aquelas referentes aos aspectos do desenvolvimento cognitivo deles/as.

No concernente ao aspecto físico e ao mobiliário da escola, observamos a existência de rampas distribuídas pelas áreas sociais, pisos adaptados para deficientes visuais, banheiros adaptados ${ }^{18}$ e carteiras para alunos canhotos, o que facilita o uso do espaço escolar pelos alunos, havendo, entretanto, degraus que dificultam a locomoção dele/as. Essas modificações, entretanto, situam-se apenas entre a entrada da escola e as salas de aula. A área de Educação Física, por exemplo, é repleta de degraus e o portão que dá acesso à quadra de esportes é estreito. Neste ano, não há alunos cadeirantes matriculados, o que implicaria constrangimento aos mesmos, uma vez que tal portão limitaria a passagem dos mesmos.

Relativamente ao primeiro instrumento - que, juntamente com o segundo, afere quantitativamente o grau de inclusão da escola - a pontuação da escola foi de 5,25 pontos, equivalendo a $63,3 \%$ de inclusão ${ }^{22}$.

Já em relação ao instrumento Questionário para os Diretores/Coordenadores Pedagógicos, a Escola Alpha obteve 14,8 pontos (equivalente a $87,1 \%$ do instrumento $)^{20}$. O escore dos dois instrumentos aplicados foi de 20,05, o que nos permite afirmar que a escola é $79,2 \%$ inclusiva.

Ao compararmos os dados obtidos na escola com dados oficiais (SEDUC. Tabelas 1 e 2 - Anexo), encontramos importantes questões a destacar relativamente ao número de vagas colocadas à disposição no início do ano versus o de alunos matriculados. Assim é que a escola ofereceu (segundo o site da SEDUC) 368 vagas, tendo, entretanto, matriculado 687 alunos. Deste universo, exposto (no referido site) por meio de uma tabela, constam dados acerca do número de alunos da educação especial (como alunos regularmente matriculados). Tais dados estão inseridos na forma de hiperlink, dando a 
aparência de constituírem um número de alunos à parte do sistema regular dentre os matriculados na escola. Em outras palavras, a escola oferece, em um primeiro olhar, o Ensino Fundamental (5a. a $8^{\mathrm{a}}$. séries), as 1a. e $2^{\mathrm{a}}$. etapas da Educação de Jovens e Adultos (Ensino Fundamental e Médio), o Ensino Fundamental de nove anos e Educação Especial (Ensino Fundamental). Para a modalidade educação especial (oferecida em todos os níveis - o que constatamos em virtude da aplicação do primeiro instrumento da pesquisa), a escola disponibilizou 58 vagas, mas matriculou 21 alunos. Segundo os dados obtidos na escola a proporção dos alunos considerados em S. I. para com os alunos regulares é de 3,9\%, uma porcentagem baixa relativamente ao estabelecido por Crochík et al. (2011, p. 77) - que é estar entre 9,5\% a $19,5 \%$ - em virtude dos estudos realizados para verificação da validade do conteúdo e da fidedignidade do Formulário para caracterização de escolas inclusivas, instrumento criado pelo autor, tendo como fundamento o Index, de autoria de Booth e Ainscow. Se as vagas disponíveis correspondessem ao número real de alunos matriculados essa proporção aumentaria para 8,7\%, distanciando-se menos do ideal proporcional.

O grau de inclusão da escola Alpha, segundo a pontuação obtida nos dois primeiros instrumentos foi consideravelmente alta, isto é, $79,2 \%$ inclusiva. Contudo, não é somente a soma destes dois instrumentos que constata o quanto uma escola é ou não inclusiva, dado realizarmos a análise qualitativa dos outros dados coligidos ao longo da pesquisa (acima parcialmente apresentados).

Nas palavras de Crochík et al. (2011, p. 83):"O instrumento também torna visível o fato de que, muito embora uma escola tenha obtido um escore alto em determinada categoria do formulário, isso não significa que, necessariamente, ela tem um grau de inclusão alto".

Essa contradição, que não é aparente, indica que ter as condições materiais e discursos adequados à inclusão não significa inclusão propriamente dita, são condições importantes, mas por si só não bastam. Os dados das observações e das entrevistas - que contradizem a mensuração desses dois instrumentos - indicam a existência de diversas perspectivas acerca da educação inclusiva na escola; tais perspectivas podem ou não estar sendo 
explicitadas; quando não o são, certamente não é a inclusão que é facilitada, mas o seu contrário. Sem o engajamento convicto de todos os educadores não há educação que dê certo.

Escola alpha: percepções sobre inclusão

O Questionário para os Diretores/Coordenadores Pedagógicos foi aplicado junto à professora Solange (vice-diretora da escola), que se encontrava envolvida em outras atividades, o que exigiu certa pressa em suas respostas. Mas, a mesma não soube responder algumas das questões desse instrumento e encaminhou-nos para os professores da S. M. Decidimos, posteriormente, entrevistar também o Coordenador Pedagógico da Escola, entrevista à qual nos referiremos mais adiante.

Com a aplicação do segundo instrumento da pesquisa, obtivemos novas informações que nos permitem distinguir as concepções de inclusão que circulam na escola. Dentre elas, ressaltamos que a Escola Alpha aceita a matrícula de qualquer aluno considerado em S. de I., mas tal aceitação está condicionada à apresentação - no ato da matrícula - de um laudo médico atestando a deficiência do aluno. A justificativa apresentada para tal controle foi a da restrição quanto ao número de alunos considerados em $\mathrm{S}$. de l. em cada sala de aula, dada a proporção a ser mantida entre os alunos com deficiência(s) e os regulares (01 aluno considerado em $\mathrm{S}$. de l. equivale a 05 regulares).

A política de inclusão da escola tem como fundamento, conforme explicitado por um professor da S. M., o respeito mútuo:"[...] todos são aceitos de forma diferenciada, valorizando a diversidade e potencialidade de cada um, independente de suas limitações".

No seio desta mesma política, a escola objetiva, igualmente, enfatizar o aprendizado e a socialização para todos, indistintamente. As dificuldades específicas de cada deficiência, porém, são trabalhadas na S. M. ${ }^{21}$, enquanto os aspectos à socialização dos alunos considerados em S. I. ${ }^{22}$ são trabalhados na sala de aula regular. Para esses, a frequência nas unidades de atendimentos especiais é obrigatória, no contraturno. Observa-se que essas unidades localizam-se fora da escola e podem ser públicas ou privadas ${ }^{23}$. Lemos, entretanto, na Resolução 001/05 de Janeiro de 2010: 
$\S 2^{\circ}$ Os atendimentos especificados no parágrafo anterior ${ }^{24}$ e no caput deste artigo deverão ser previstos e assegurados aos alunos com necessidades educacionais especiais pelo Sistema Público Estadual, mediado pelo setor próprio do Sistema de Ensino. (GOVERNO DO ESTADO DO PARÁ, 2012).

Quanto à atenção a estes alunos, há um professor da S. M. responsável por auxiliá-los no momento de realização das provas. Em uma das observações realizadas (em um dia de prova), pudemos verificar que os alunos considerados em S. de l., que estavam realizando a prova, não contaram com o referido acompanhamento. Em uma conversa informal com uma das professoras da classe esta comentou que, dificilmente, um professor da S. M. vai à sala de aula para acompanhá-los.

Ainda ao longo da aplicação do Questionário para Diretores..., informaram-nos que: as salas de aula da escola são formadas por alunos com desempenhos heterogêneos; o currículo e a avaliação são diversificados conforme a necessidade de cada aluno considerado em S. de I., ainda que a escola trabalhe para manter os pais participantes na formação de seus filhos, promovendo eventos, palestras, reuniões, campanhas para minimizar a violência e o bullying.

Dadas as contradições entre as diferentes concepções de inclusão subsumidas nas falas dos entrevistados, formal e informalmente, procuramos o Coordenador Pedagógico da Escola, professor Eriberto, que defende a necessidade de a Secretaria de Estado de Educação (SEDUC) capacitar os professores interessados em trabalhar na perspectiva da educação inclusiva, pois, caso os mesmos tivessem interesse em atuar nesta perspectiva, teriam procurado, no início de sua formação, especializar-se e se capacitarem para tanto:

A SEDUC deve capacitar os professores nessa área, porém eles devem querer, é preciso saber se os mesmos querem ser capacitados, pois se os professores quisessem ser capacitados eles teriam, desde o princípio da sua formação, buscado uma especialização, um curso que os capacitasse para trabalhar com os alunos deficientes. Agora, se o professor não quer, não gosta e não escolheu trabalhar nessa área fica mais complicado; vai ter que trabalhar com esses alunos por causa da lei, mas não se pode cobrar muito dele, pois não foi isso que escolheu pra trabalhar. (ERIBERTO, Abril de 2012). 
Ao longo da entrevista, o professor Eriberto esboçou sua opinião contrária à forma como vem ocorrendo a inclusão nas escolas, principalmente, na escola na qual trabalha. Segundo ele, os alunos estão sendo matriculados - por força da legislação em vigor - nas salas de aula do ensino regular, porém se deparam com professores insuficientemente capacitados que, sem saber como trabalhar com os mesmos (relativamente ao conteúdo e à metodologia ${ }^{25}$ ), sentem-se inseguros quanto à possibilidade de educar/ensiná-los. Uma das "soluções" referidas por ele seria o acompanhamento dos alunos por profissionais formados para esse trabalho (professores especializados), justificando que"[...] um profissional formado para este fim saberia lidar com estes alunos e principalmente estaria interessado neste trabalho" (ERIBERTO, Abril de 2012). O Coordenador Pedagógico afirmou ainda que os professores, ao escolherem sua profissão, não esperavam encontrar "esse tipo de trabalho", que não escolheram "isto" para a sua profissão e que agora, por força da lei, são obrigados a trabalhar com todos, a adequarem-se às necessidades do aluno. Segundo Eriberto, são os alunos que devem se adequar aos professores e não vice-versa. Tal concepção levou-o ao seguinte questionamento:"quem se adéqua a quem?".

Importante ressaltar que não é de interesse da educação inclusiva priorizar ou somente viabilizar as adaptações necessárias aos alunos considerados em situação de inclusão, mas sim a todos. Segundo Crochík (2011, p. 72):

[...] a inclusão deve levar em conta todos os participantes da educação, pois, do contrário, ao priorizar apenas aqueles com 'necessidades educacionais especiais', as dificuldades dos demais podem não ser contempladas e as dos que são assim classificados podem ser superestimadas.

Sobre a inclusão para todos, Eriberto afirma ser responsabilidade do Estado investir financeiramente na educação, pois somente assim haverá avanço.

Incluir alunos considerados em situação de inclusão em salas de aula regulares exige, para o Coordenador da Escola Alpha, a presença de um profissional especializado em sala de aula para auxiliar o professor não especialista, de modo a não haver uma sobrecarga demasiado grande para o último que, muitas vezes, não sabe como lidar com as dificuldades específicas de cada aluno. 
Novamente, deparamo-nos com a subsunção da educação especial no sistema regular de ensino, contrariamente à nossa luta por uma inclusão não segregadora. Nas palavras de Crochík (2012, p. 44):

Dentro das propostas de educação inclusiva, existe uma que, a nosso juízo, é pior do que a denominada educação integrada, ainda que melhor do que a segregada: a educação especial móvel [...]; trata-se de proposta que traz um professor formado e experiente em educação especial para sala de aula para se responsabilizar pelos alunos com deficiência, o que implica construir um 'muro simbólico' entre os alunos regulares ${ }^{26} \mathrm{e}$ os considerados em situação de inclusão. Isso, de modo similar, já ocorre, com certa frequência, principalmente nas escolas particulares, e se realiza por meio de auxiliares de professor; esse profissional passa a ser conhecido como sendo próprio a esses alunos o que configura uma segregação dentro da própria sala de aula, o que a nosso ver, fortalece o preconceito, não o combate. Como escrito antes, não se trata de desconhecer que os alunos com deficiências necessitem, por vezes, recursos específicos, mas isso não significa que deva haver isolamento desses alunos em relação a seus colegas.

Quanto à diversificação do currículo em conformidade com as necessidades dos alunos, o Coordenador, contrariando a informação vinda dos docentes da S. M., afirmou que em sala de aula o conteúdo das diferentes disciplinas é o mesmo para todos.

Relativamente às Observações em Sala de Aula, realizamos duas observações: uma em uma aula de Matemática e outra na de História. Para preservar a identidade dos dois alunos considerados em S. de I. da 4a. Série, matriculados na sala observada, chamamo-los João e Maria, por serem, respectivamente, do sexo masculino e feminino. Muito embora ambos apresentem deficiências múltiplas, têm comportamentos distintos. Maria não fala nada durante as aulas, nem se relaciona com seus colegas de turma, sentando-se ao lado de uma das paredes da sala, na primeira carteira. Aí permanece durante a aula, quase que totalmente esquecida por parte dos colegas e da professora. Em contrapartida, João comporta-se de modo mais ativo, tem seu ciclo de amigos, sentando-se no meio da sala. Chama atenção para si, com brincadeiras que incitam seus colegas de turma a brigarem, o que faz com que a professora passe grande parte da aula a repreendê-lo. 
O tratamento dispensado pela professora a Maria e João é o mesmo que para todos os alunos: não observamos uma preocupação especial da mesma para com os alunos considerados em $\mathrm{S}$. de I., no sentido de acompanhá-los diferenciadamente em relação ao conteúdo socializado. Conteúdo e atividades são os mesmos para todos. Aparentemente, o tratamento diferenciado para estes alunos restringe-se à S. M., conforme revelado pelos professores que nela trabalham. João e Maria estão, pois, integrados na sala de aula regular, não se percebendo, assim, atitudes inclusivas por parte dos professores. Crochík e Crochík (2011, p. 146), ao comentarem o trabalho desenvolvido na Escola da Ponte, afirmam:

Pacheco et al. (2007) [...] argumentam que na Escola da Ponte, os currículos são diversificados para todos, não só para os alunos que pertencem a minorias. Assim, a educação inclusiva não visa somente os alunos considerados com necessidades educacionais específicas, mas a todos os estudantes. Dessa maneira, a perspectiva de entender pessoas que possuem dificuldades de participar do cotidiano escolar muda de forma; é possível que os alunos se identifiquem entre si a partir do momento que percebam que nem todos se interessam pelo mesmo assunto e que nem todos aprendem da mesma forma.

Tal possibilidade de identificação entre os diferentes talvez propiciasse uma saída tanto para os comportamentos apresentados por Maria e João, quanto para o de seus colegas em relação a eles.

Uma professora de Educação Física, em conversa informal, relatou-nos sua dificuldade relativamente a seu trabalho com os alunos considerados em S. de I., pois não se sente capacitada para trabalhar com os mesmos, haja vista não ser uma profissional da educação especial. Igualmente ao coordenador pedagógico, esta professora considera importante o acompanhamento de um profissional específico para esses alunos, na sala de aula regular e igualmente nas suas aulas, na quadra de esportes. Partindo do princípio de que não havendo esse professor especial, cabe à mesma realizar um planejamento especial para cada aluno, ainda que ela não seja capacitada para tanto, pergunta a professora:

Para cada aluno desses, eu terei que fazer um planejamento de aula? Vou ter que me adequar a cada um deles? Assim vou ficar louca, vai chegar 
um dia que vou ter que fazer uns dez planejamentos diferentes para cada uma das deficiências.

CONCLUSÕES PROVISÓRIAS OU QUANDO AS (IN)CERTEZAS SÃO ILUMINADAS...

Como as propostas da educação inclusiva preveem modificações substanciais na arquitetura da escola, nos métodos de ensinar e avaliar, mesmo quando alunos com deficiência são aceitos, não necessariamente têm condições de ser incluídos; quando tais alterações não são feitas, temos o que é denominado educação integrada [...], que se já significa um bom avanço em relação à educação segregada, ainda não possibilita a plena inclusão dos alunos antes segregados, quer porque estudavam em instituições especiais/classes especiais, ou porque não estudavam em nenhum lugar. A proposta de educação inclusiva implica o reconhecimento das diferenças e as adequadas condições para que essas não sejam obstáculo à formação; assim, linguagem em braile pode ser importante para os que têm deficiência visual; linguagem dos sinais pode ser importante para os que têm deficiência auditiva; falar mais pausadamente e utilizar mais recursos imagéticos pode ser importante para os que têm deficiência intelectual. A educação inclusiva, assim, não pode desconhecer as diferenças no que elas implicam possíveis obstáculos ou facilidades para o cumprimento dos objetivos escolares. (CROCHÍK, 2012, p. 41).

Expusemos dados parciais da pesquisa Educação e Políticas Públicas: exclusão social e educação inclusiva em escolas da região Norte (PA/BR). Em meio a essa provisoriedade da pesquisa, parece evidenciar-se que a Escola Alpha experimenta o início de um processo que tende à inclusão, principalmente em função de os discentes viverem o que se configura como modelo da integração que não é o ideal da educação inclusiva, sendo, entretanto, comparativamente à educação segregadora "melhor" para os alunos em situação de inclusão.

Arriscamos, ainda, pontuar - por meio de nossa imersão na realidade em que se situa nosso objeto de estudo - o quanto o ideário dos profissionais da educação inclusiva ainda permanece arraigado ao tradicional dado o incômodo que lhes causam os diferentes, os 'incluídos' na educação inclusiva. Do ponto de vista físico-espacial, observamos que a escola vem se adaptando às necessidades dos alunos, havendo, contudo, também nesse aspecto, problemas a serem superados. 
Observamos, também, que os alunos considerados em situação de inclusão ocupam as salas regulares que, apesar da presença dos diferentes, continuam atendendo principalmente as necessidades dos alunos tidos como normais. Dito de outro modo, parece-nos que a escola continua a ser um local em que os diferentes estão apenas integrados, haja vista seus diferentes espaços não serem destinados para todos os alunos da escola, com ou sem deficiência(s).

Do ponto de vista quantitativo, pela somatória alcançada pela escola nos dois primeiros instrumentos da pesquisa, o grau de inclusão da escola Alpha pode ser considerado alto, mas há muitos aspectos qualitativos adversos a esses números, que fazem com que reflitamos o quanto a escola tem ou não incluído/excluído.

Quanto à visibilidade que se deixou iluminar relativamente aos alunos considerados em situação de inclusão, podemos afirmar a necessidade de modificar / rever que caminho seguir para uma inclusão possível nesta sociedade, mais ampla do que a existente, o que, por sua vez, implica a necessidade de uma reviravolta nas nossas concepções acerca da inclusão e dos processos excludentes que se reproduzem na escola; modificações na estrutura física da escola; nas políticas públicas voltadas à educação e no comprometimento com uma democratização substantiva da sociedade e das escolas. Implica, também, compreendermos a importância de nossas teorias e práticas enquanto trabalhadores da educação, bem como a de nosso trabalho no concernente à formação e inclusão de todos, independentemente de suas potencialidades, dificuldades ou limitações.

Ao provisório da conclusão, uma passagem de Benjamin (1987, p. 239) anima-nos, ainda, como os homens que escavam, a dar sequência à busca de fatos que melhor nos conduzam a ler seus significados:

Antes de tudo, não deve temer [o homem que escava] voltar sempre ao mesmo fato, espalhá-lo como se espalha a terra, revolvê-lo como se revolve o solo. Pois 'fatos' nada são além de camadas que apenas à exploração mais cuidadosa entregam aquilo que recompensa a escavação. 
CRITICAL THEORY, FORMATION, INDIVIDUAL AND PREJUDICE: A GLIMPSE AT THE SCHOOLS IN THE NORTHERN REGION (PA/BR)

ABSTRACT: The subject of this article - attached to the research Education and Public Politics: social exclusion and inclusive education in schools of the Norte region (PA/BR), that constitutes one of the subprojects of the investigation Prejudice in relation to those included in inclusive education on-going research in (inter) national level - focuses on the issue of inclusive education. We elect as the problem for discussion the relationship between social exclusion and social inclusion aiming to think - using documentary sources, articles and/or similar works, as well as empirical data already collected - if other forms of exclusion may have origin (intentional tendency or not) in the current forms/contents of inclusion, given the existence of prejudice, taken as central hypothesis of both related researches. We consider the relevance of contributing to the formation (in the direction assigned to this concept on the thinking of the Frankfurtians) of educational workers taking into account the importance of the confrontation of prejudiced attitudes in the formal education. The partial results of the research indicate the relevance of theory to the understanding of the object we are dealing with, that is, the prejudice that may fall on the students considered in situation of inclusion in regular schools, as well as for the reading that has been done on the inclusive education.

KeYwords: Critical Theory of Society. Formation. Prejudice. Education. Inclusive Education.

TEORÍA CRÍTICA, FORMACIÓN, INDIVIDUO Y PREJUICIO: UNA MIRADA A LAS ESCUELAS DE LA REGIÓN NORTE (PA/BR)

RESUMEN: El tema de este artículo - vinculado a la investigación Educación y Políticas Públicas: exclusión social y educación inclusiva en las escuelas de la región norte (PA/BR), que es uno de los sub-proyectos alojados en la encuesta Prejuicios contra el "incluidos" en la educación inclusiva, en curso en el nivel (inter)nacional - se centra en el tema de la educación inclusiva. Hemos elegido como problema para discusión la relación entre exclusión y inclusión social, en el sentido de pensar - basándonos en fuentes documentales, en artículos y/o de obras similares, así como en datos empíricos ya recogidos - si otras formas de exclusión pueden tener origen (tendencia internacional o no) en las actuales formas/contenidos de la inclusión, dada la existencia de prejuicios, tomado como hipótesis central de dicha investigación. Nuestra intención es contribuir para la formación (en el sentido que atribuyen a este concepto los Frankfurtianos) de los trabajadores de la educación en vista de la importancia de hacer frente a las actitudes prejuiciosas dentro del proceso de educación formal. Los resultados parciales de la encuesta indican la importancia de la teoría para la comprensión del objeto de 
que nos ocupamos, es decir, el prejuicio que puede caer sobre los estudiantes considerados en situación de inclusión en las escuelas ordinarias, así como para la lectura que sobre la educación inclusiva se ha hecho.

Palabras clave: Teoría Crítica de la Sociedad. Formación. Prejuicio. Educación. Educación Inclusiva.

\section{NOTAS}

1) Nessa direção é que, talvez, possamos compreender o porquê das transformações de conceitos que designam deficiências, a exemplo da história do conceito deficiência intelectual. A esse respeito registramos as afirmações de Sassaki (2012): "À medida que o movimento inclusivo se espalha pelo mundo, palavras e conceituações mais apropriadas ao atual patamar de valorização dos seres humanos estão sendo incorporadas ao discurso dos ativistas de direitos, por exemplo, dos campos da deficiência e da saúde mental". Ainda no mesmo artigo, ao distinguir os conceitos deficiência intelectual e mental, o autor afirma: "Ao longo da história, muitos conceitos existiram e a pessoa com esta deficiência já foi chamada, nos círculos acadêmicos, por vários nomes: oligofrênica; cretina; tonta; imbecil; idiota; [...]; deficiente mental em nível leve, moderado, severo ou profundo (nível estabelecido pela Organização Mundial da Saúde, 1968); criança com déficit intelectual; criança com necessidades especiais; criança especial etc. Mas, atualmente, quanto ao nome da condição, há uma tendência mundial (brasileira também) de se usar o termo deficiência intelectual [...]". O autor conclui que a melhor adequação do termo deficiência intelectual deve-se ao fato de o mesmo referir-se, especificamente, ao funcionamento do intelecto e não ao funcionamento da mente como um todo (Cf. SASSAKI, 2012).

2) "Com a dissolução do contrato através de sua observância literal, altera-se a posição histórica da linguagem: ela começa a transformar-se em designação. $\mathrm{O}$ destino mítico, fatum, e a palavra falada eram uma só coisa. A esfera das representações a que pertencem as sentenças do destino executadas invariavelmente pelas figuras míticas ainda não conhece a distinção entre palavra e objeto. A palavra deve ter um poderio imediato sobre a coisa, expressão e intenção confluem. A astúcia, contudo, consiste em explorar a distinção, agarrando-se à palavra, para modificar a coisa. [...] Na fase homérica, essa oposição torna-se determinante. [...] É do formalismo dos nomes e estatutos míticos, que querem reger com a mesma indiferença da natureza os homens e a história, que surge o nominalismo, o protótipo do pensamento burguês. [...] Essa adaptação pela linguagem ao que está morto contém o esquema da matemática moderna". (HORKHEIMER; ADORNO, 1985, p. 65). 
3) Lemos em Horkheimer e Adorno (1985, p. 153-4): “Distintos e inseparáveis, a palavra e o conteúdo estavam associados um ao outro. Sua forma constituía-os e, ao mesmo tempo, refletia-os. A decisão de separar o texto literal como contingente e a correlação com o objeto como arbitrária acaba com a mistura supersticiosa da palavra e da coisa. O que, numa sucessão determinada de letras, vai além da correlação com o evento é proscrito como obscuro e como verbalismo metafísico. Mas deste modo a palavra, que não deve significar mais nada e agora só pode designar, fica tão fixada na coisa que ela se torna uma fórmula petrificada. Isso afeta tanto a linguagem quanto o objeto. Ao invés de trazer o objeto à experiência, a palavra purificada serve para exibi-lo como instância de um aspecto abstrato, e tudo o mais, desligado da expressão (que não existe mais) pela busca compulsiva de uma impiedosa clareza, se atrofia também na realidade".

4) Importa sublinhar o dizer de Crochík quanto à citação de Horkheimer e Adorno (1978): "Adorno não nega a contradição existente no emprego da estatística, num momento de despersonalização, com a qual a lei dos grandes números colabora; [...]. Diferentemente do culto ao fato, esse [...] serve para reflexão, para que a sua determinação fique visível e consequentemente, quando for o caso, esse conhecimento sirva à luta para modificar as condições que o geraram". (CROCHÍK, 2009, p. 299).

5) “Esta [a irrefreável regressão] não se limita à experiência do mundo sensível, que está ligada à proximidade das coisas mesmas, mas afeta ao mesmo tempo o intelecto autocrático, que se separa da experiência sensível para submetê-la. A unificação da função intelectual, graças à qual se efetua a dominação dos sentidos, a resignação do pensamento em vista da produção da unanimidade, significa o empobrecimento do pensamento bem como da experiência: a separação dos dois domínios prejudica a ambos" (HORKHEIMER; ADORNO, 1985, p. 46-7).

6) Antes de iniciarmos a aplicação dos instrumentos da pesquisa, propomos aos sujeitos que, livremente, aceitam participar da pesquisa, a assinatura de um Termo de Consentimento Livre e Esclarecido (TCLE).

7) Estes dois instrumentos da pesquisa foram aplicados durante o $1^{\circ}$. semestre letivo de 2012 junto à Escola Alpha. Em virtude de questões relativas à distinção entre os diversos relatos advindos da convivência na escola realizamos - para além dos instrumentos propostos - uma entrevista, em separado, com o Coordenador Pedagógico da escola.

8) Alunos considerados em Situação de Inclusão (S. de I.) é a expressão adotada pelos docentes pesquisadores envolvidos na pesquisa Preconceito em relação aos 'incluídos' na educação inclusiva para designar os alunos que antes não estudavam ou o faziam em escolas/classes especiais.

9) Conforme Anderson (1995, p. 9), "A chegada da grande crise do modelo econômico do pós-guerra, em 1973, quando todo o mundo capitalista avançado caiu numa 
longa e profunda recessão, combinando, pela primeira vez, baixas taxas de crescimento com altas taxas de inflação, mudou tudo. A partir daí as ideias neoliberais passaram a ganhar terreno. As raízes da crise, afirmavam Hayek e seus companheiros, estavam localizadas no poder excessivo e nefasto dos sindicatos e, de maneira mais geral, do movimento operário, que havia corroído as bases de acumulação capitalista com suas pressões reivindicativas sobre os salários e com sua pressão parasitária para que o Estado aumentasse cada vez mais os gastos sociais".

10) Conforme Kassar (1998): “O neoliberalismo encontra suas raízes na Europa dos anos 40, mas se apresenta como propostas econômicas e programas políticos na década de 1970. Trata-se de 'uma reação teórica e política veemente contra o Estado intervencionista e de Bem-Estar' (Anderson 1996, p. 9), com denúncias à limitação da liberdade econômica e política, pregando o valor da desigualdade natural, imprescindível à concorrência e à prosperidade social. Com uma nova roupagem e discurso consistente, o neoliberalismo, assim como o liberalismo, pode ser identificado por sua fundamentação positivista, que toma 'os fenômenos como sujeitos a leis naturais invariáveis' (COMTE, 1983, p. 7). Por esse enfoque, não existe a percepção do movimento social como ação histórica humana. Contrariamente, a evolução da sociedade é explicada por um élan 'natural', regida por leis naturais, tal como os fenômenos da natureza" (KASSAR, 1995, p. 18).

11) A Convenção - adotada pela Resolução n. L. 44 (XLIV) da Assembleia Geral das Nações Unidas, em 20 de novembro de 1989 e ratificada pelo Brasil em 20 de setembro e 1990 - foi corroborada pela quase totalidade dos Estados-membros da ONU (Organização das Nações Unidas) à exceção da Somália e dos Estados Unidos da América (Cf. verbetes da WIKIPÉDIA, 2011).

12) A Declaração Universal dos Direitos Humanos foi adotada pela Organização das Nações Unidas em 10 de dezembro de 1948.

13) Lemos na Declaração Mundial sobre Educação para Todos (UNESCO, 2011): “Há mais de quarenta anos, as nações do mundo afirmaram na Declaração Universal dos Direitos Humanos que 'toda pessoa tem direito à educação'. No entanto, apesar dos esforços realizados por países do mundo inteiro para assegurar o direito à educação para todos, persistem as seguintes realidades: Mais de 100 milhões de crianças, das quais pelo menos 60 milhões são meninas, não têm acesso ao ensino primário; mais de 960 milhões de adultos - dois terços dos quais mulheres são analfabetos, e o analfabetismo funcional é um problema significativo em todos os países industrializados ou em desenvolvimento; mais de um terço dos adultos do mundo não têm acesso ao conhecimento impresso, às novas habilidades e tecnologias, que poderiam melhorar a qualidade de vida e ajudá-los a perceber e a adaptar-se às mudanças sociais e culturais; E mais de 100 milhões de crianças e incontáveis adultos não conseguem concluir o ciclo básico, e outros milhões, apesar de concluí-lo, não conseguem adquirir conhecimentos e habilidades essenciais". (UNESCO, 2011). 
14) Segundo dados definitivos do Censo do IBGE/2010, publicados em 16 de novembro de 2011: "Metade da população recebeu mensalmente, durante o ano de 2010, até R\$ 375 - valor inferior ao salário mínimo, de R\$ 510, pago na época. No que se refere ao rendimento médio mensal domiciliar, os $10 \%$ com os rendimentos mais elevados ganhavam $R \$ 9.501$, enquanto as famílias mais pobres viviam com apenas R\$ 225 por mês". (AGÊNCIA BRASIL, 2011).

15) Presidente do Banco Mundial no período compreendido entre 1995 a 2005.

16) Os nomes da Escola, dos professores e alunos aos quais fazemos referência foram alterados para preservar suas identidades.

17) Questões acrescidas: Em sua opinião, a iniciativa de capacitação do professor deveria partir do profissional ou da SEDUC? Os alunos com necessidades especiais devem estar nas salas de aula regulares? Os alunos com necessidades especiais estão incluídos ou integrados? A política de inclusão está bem fundamentada? A escola aceita matrícula de alunos em liberdade assistida? Quais meios a escola utiliza para favorecer a aprendizagem/socialização/integração das crianças consideradas em situação de inclusão na sala de aula? Os profissionais da sala multifuncional são três por turno? A escola promove palestras, reuniões sobre inclusão para os pais, professores?

18) Importa ressaltar que os banheiros adaptados (um feminino e outro masculino) estão regularmente fechados. As chaves para abri-los ficam nas mãos dos profissionais da sala multifuncional, sendo assim, quando há a necessidade de utilização, é necessário recorrer a um desses profissionais.

19) Segundo Crochík (2011), a pontuação máxima deste instrumento é de 8,3 pontos. Portanto, quanto mais próxima deste escore estiver a pontuação obtida pela escola pesquisada, mais inclusiva ela será considerada.

20) O escore máximo deste instrumento é de 17 pontos: quanto maior for a pontuação da escola maior seu grau de inclusão. A Escola Alpha neste instrumento alcançou 14,8 pontos, obtendo assim um grau de inclusão de $87,1 \%$.

21) A Sala Multifuncional é de uso específico dos alunos considerados em S. de I.

22) Dentre as várias contradições encontradas ao longo da realização da pesquisa, esta é uma delas: contrariamente à informação deste professor da S. M., segundo a Vice-Diretora, em sala de aula, são trabalhados os aspectos relativos à socialização e ao aprendizado.

23) A unidade pública de atendimento Álvares de Azevedo, por exemplo, oferece um atendimento especial aos deficientes visuais desta Escola.

24) Afirma a Resolução Nº 001 de 05 de Janeiro de 2010, do CNE do Governo do Estado do Pará (2012) no parágrafo mencionado: "Quando se fizer necessário diagnóstico e/ou acompanhamento terapêutico por profissionais de outras áreas (médica, 
psicológica e outras) e/ou acompanhamento pedagógico individualizado, caberá ao Estado a oferta dos mesmos, cabendo à família a responsabilidade de acompanhar o respectivo atendimento apropriado ao educando".

25) Acrescentaríamos que, igualmente, em relação à avaliação pode-se afirmar o mesmo.

26) De outro lado - o que apenas inverte os sinais, deixando intocada a concepção proposta - qualquer dificuldade que um aluno regular venha a ter não é considerada relevante. Os alunos não diagnosticados com alguma necessidade diferenciada não são atendidos na S. M., pois são alunos normais. Qualquer dificuldade que venham a ter é encaminhada à Coordenação, que tenta solucionar o problema e, por vezes, quando cabe, aciona os pais do aluno. Afirmou, ainda, o coordenador que, dificilmente, há um trabalho com estes alunos, pois há muito serviço para poucos profissionais, sendo ele, por exemplo, o único coordenador do período da tarde, o que dificulta seu trabalho no que concerne às dificuldades dos demais alunos.

\section{REFERÊNCIAS}

ADORNO, T.W et al. La personalidad autoritaria. Buenos Aires: Editorial Proyección, 1965.

ANDERSON, P. Balanço do neoliberalismo. In: SADER, Emir \& GENTILI, Pablo (Org.). Pós-neoliberalismo: as políticas sociais e o Estado democrático. Rio de Janeiro: Paz e Terra, 1995, p. 09-23.

BENJAMIN, W. Rua de mão única. São Paulo: Brasiliense, 1987. (Obras Escolhidas, v. 2).

BRASIL. MEC. Instituto Nacional de Estudos e Pesquisas Educacionais Anísio Teixeira. Resumo Técnico - Censo Escolar 2010. Disponível em:<http://download.inep.gov.br/ educacao_basica/censo_escolar/resumos_tecnicos/divulgacao_censo2010_revisao_04022011.pdf>. Acesso em: out.2011.

BRASIL. MEC. LEI No 10.436, de 24 de abril de 2002. Dispõe sobre a Língua Brasileira de Sinais - Libras e dá outras providências. Disponível em: <http://portal.mec.gov. br/arquivos/pdf/lei10436.pdf>. Acesso em: nov. 2011.

BRASIL. MEC. SEESP. Declaração de Salamanca: Sobre Princípios, Políticas e Práticas na Área das Necessidades Educativas Especiais. Disponível em: <http://portal.mec. gov.br/seesp/arquivos/pdf/salamanca.pdf>. Acesso em: set. 2009.

BRASIL. MEC. CONAE. Documento Base da Conferência Nacional da Educação (2010).

Disponível em: <http://conae.mec.gov.br/images/stories/pdf/pdf/documetos/ mec\%20-\%20doc\%20base\%201\%20-\%20email_sl.pdf>. Acesso em: out.2012.

COHN, G. A Sociologia como ciência impura (Introdução à Introdução à sociologia). In: ADORNO, Th. Introdução à sociologia. São Paulo: UNESP, 2008. 
CROCHÍK, J. L.; CROCHÍK, N. Teoria crítica e educação inclusiva. In: InterMeio: Revista do Programa de Pós-Graduação em Educação, Campo Grande, MS, v.14, n.28, p.134150, jul./dez. 2008. Disponível em: <http://www.intermeio.ufms.br/revistas/28/InterMeio_v14_n28\%20Jose.pdf>. Acesso em: mar. 2010.

. Preconceito, indivíduo e cultura. São Paulo: Robe Editorial, 1997.

.Preconceito em relação aos 'incluídos' na educação inclusiva. São Paulo: IPUSP, 2008 (impresso).

. Indivíduos com predisposição ao preconceito. In: . Preconceito, indivíduo e cultura. São Paulo: Casa do Psicólogo, 2006.

T. W. Adorno e a Psicologia Social. In: Psicologia \& Sociedade; 20 (2): 287-296, 2008. Disponível em: <http://www.scielo.br/pdf/psoc/v20n2/a17v20n2.pdf >. Acesso em: jan. 2009.

. et al. Análise de um formulário de avaliação de inclusão escolar. In: Imagens da Educação, v. 1, n. 2, p. 71-87, 2011.

Educação inclusiva e preconceito. Desafios para a prática pedagógica. In: MIRANDA, T. G.; FILHO, T. A. G. O professor e a educação inclusiva. Salvador: Edufba, 2012. p. 39-59.

FELTRIN, A. E. Inclusão social na escola: quando a pedagogia se encontra com a diferença. São Paulo: Paulinas, 2007. 167p.

GOVERNO DO ESTADO DO PARÁ. CONSELHO ESTADUAL DE EDUCAÇÃO. Resolução $N^{\circ} 001$ de 05 de Janeiro de 2010. Dispõe sobre a regulamentação e a consolidação das normas estaduais e nacionais aplicáveis à Educação Básica no Sistema Estadual de Ensino do Pará. Disponível em: <http://www.cee. pa.gov.br/sites/default/files/RESOLU\%C3\%87\%C3\%830\%20001.2010\%20 REGULAMENTA\%C3\%87\%C3\%830\%20EDUC.\%20BAS.pdf>. Acesso em: ago.2012.

KASSAR, M. de C. M. Liberalismo, neoliberalismo e educação especial: algumas implicações. Cad. CEDES. Campinas, v. 19, n. 46, set.1998. Disponível em: <http://www. scielo.br/scielo.php?script=sci_arttext\&pid=S0101-32621998000300003\&lng=pt\&n rm=iso >. Acesso em: 13 nov. 2011.

MACHADO, J. P. e PAN, M. A. G. de S. Do Nada ao Tudo: políticas públicas e a educação especial brasileira. In: Educação e Realidade, Porto Alegre, v. 37, n. 1, p. 273-94, jan./abr. 2012.

Marcuse, H. Eros e Civilização. Rio de Janeiro, Zahar, 1981.

MARTINS, J. de S. Exclusão social e a nova desigualdade. São Paulo: Paulus, 1997.

MARX, K. O Capital: crítica da Economia Política. Volume I. 9.ed. São Paulo, Difel, 1984. 
ORREGO L., C. et al. Prejuicio y discriminación étnica: una expresión de prácticas pedagógicas de exclusión. In: Revista Latinoamericana de Educación Inclusiva. Escuela de Educación Diferencial, Facultad de Ciencias de la Educación de la Universidad Central de Chile en colaboración con RINACE, Red Iberoamericana de Investigación sobre Cambio y Mejora de la Escuela. Septiembre 2009 / Número 2 / Volumen 3, p. 165-79. Disponível em: <http://www.rinace.net/rlei/numeros/vol3-num2/art10. pdf $>$. Acesso em Janeiro de 2012.

PATTO, M. H. S. Mutações no cativeiro: escritos de Sociologia e Psicologia. São Paulo: Hacker/EDUSP, 2000.

SASSAKI, R. K. Atualizações semânticas na inclusão de pessoas: Deficiência mental ou intelectual? Doença ou transtorno mental? In: Revista Nacional de Reabilitação, ano IX, n. 43, mar./abr. 2005, p.9-10. Disponível em: <http://www.educacaoonline. pro.br/index.php?option=com_content\&view=article\&id=68:atualizacoes-semanticas-na-inclusao-de-pessoas-deficiencia-mental-ou-intelectual-doenca-ou-transtorno-mental\&catid=6:educacao-inclusiva\&ltemid=17> . Acesso em: fev. 2012.

SECRETARIA DE EDUCAÇÃO DO PARÁ (SEDUC). Consulta Escolas. Disponível em: $\quad<$ http://www.seduc.pa.gov.br/portal/escola/consulta_matricula/RelatorioMatriculasDetalhado.php?nome_ure=19A\%20URE\%20-\%20BELEM\&nome_ use=Unidade\%203\&codigo_escola=1736\&codigo_composicao=191\&idareatemati $\mathrm{ca}=\&$ idmenulateral=>. Acesso em: 02 ago. 2012.

SECRETARIA DE EDUCAÇÃO DO PARÁ (SEDUC). Consulta Escolas. Disponível em: $\quad<$ http://www.seduc.pa.gov.br/portal/escola/consulta_matricula/RelatorioMatriculasDetalhado.php?nome_ure=19A\%20URE\%20-\%20BELEM\&codigo_ use $=3 \&$ nome_use=Unidade $\% 203 \&$ codigo_municipio=43281\&codigo_escola=1736>. Acesso em: 02 ago. 2012.

WIKIPÉDIA. Projeto de enciclopédia multilíngue livre, colaborativo e apoiado pela organização sem fins lucrativos Wikimedia Foundation. Disponível em: <http:// pt.wikipedia.org/wiki/Wikip\%C3\%A9dia>. Acesso em: nov. 2011.

WOLFENSOHN, J. D. The challenge of inclusion. Address to the Board of Governors

Hong Kong, China. September 23, 1997. Disponível em: <http://www-wds.worldbank.org/external/default/WDSContentServer/IW3P/IB/2001/09/01/000094946_01 082204002420/Rendered/PDF/multiOpage.pdf>. Acesso em: ago.2012. 


\section{ANEXO}

FONTES OFICIAIS: Escola Alpha (2012)

CONSULTA DE MATRICULAS 2012

\begin{tabular}{|c|c|c|c|}
\hline \multicolumn{4}{|c|}{ ESCOLA ALPHA | Município: Belém } \\
\hline CURSO & $\begin{array}{c}\text { VAGAS } \\
\text { DISPONÍVEIS }\end{array}$ & $\begin{array}{c}\text { ALUNOS } \\
\text { ENTURMADOS }\end{array}$ & $\begin{array}{c}\text { TOTAL DE } \\
\text { MATRÍCULAS }\end{array}$ \\
\hline Ens. Fund. $5^{\mathrm{a}}$ a $8^{\mathrm{a}}$ séries & 123 & 216 & 217 \\
\hline Ens. Fund. EJA $1^{\text {a }}$ e $2^{\text {a }}$ Etapas & 15 & 20 & 20 \\
\hline Ens. Fund. 9 anos & 81 & 292 & 295 \\
\hline Ens. Fund. Ed. Especial & 58 & 21 & 21 \\
\hline Ens. Fund. EJA $2^{\mathrm{a}}$ e $4^{\mathrm{a}}$ Etapas & 50 & 85 & 85 \\
\hline Ens. Méd. EJA $1^{\text {a }}$ e $2^{\text {a }}$ Etapas & 41 & 49 & 49 \\
\hline TOTAL & 368 & 683 & 687 \\
\hline
\end{tabular}

Fonte: SEDUC/PA (Agosto de 2012)

CURSO: ENS. FUND. EDUCAÇÃO ESPECIAL

\begin{tabular}{lcccc}
\hline SÉRIE & TURMAS & $\begin{array}{c}\text { VAGAS } \\
\text { DISPONÍVEIS }\end{array}$ & $\begin{array}{c}\text { ALUNOS } \\
\text { ENTURMADOS }\end{array}$ & $\begin{array}{c}\text { TOTAL DE } \\
\text { MATRÍCULAS }\end{array}$ \\
\hline Déficit Cognitivo & 03 & 21 & 12 & 12 \\
\hline Déficit Visual & 02 & 03 & 01 & 01 \\
\hline Déficit Auditivo & 02 & 08 & 02 & 02 \\
\hline Déficit Físico Motor & 02 & 09 & 01 & 01 \\
\hline Déficits Múltiplos & 02 & 07 & 02 & 03 \\
\hline Condutas Típicas e Síndromes & 02 & 08 & 00 & 00 \\
\hline Altas Habilidades & 01 & 02 & $\mathbf{2 1}$ & $\mathbf{2 1}$ \\
\hline TOTAL & $\mathbf{1 4}$ & $\mathbf{5 8}$ & & 02 \\
\hline
\end{tabular}

Fonte: SEDUC/PA (Agosto de 2012) 
ROSELY CABRAL GIORDANO: Doutora em Psicologia pela Universidade de São Paulo (USP). Atualmente é docente da Universidade Federal do Pará (UFPA). Tem experiência nas áreas de Filosofia e Psicologia, atuando principalmente nos seguintes temas: Educação (Políticas Públicas), Filosofia (Teoria Crítica) e Psicologia Social (Papéis e Estruturas Sociais; Indivíduo).

E-mail:philosofi@uol.com.br

JOSÉ LEON CROCHÍK: Docente do Instituto de Psicologia da USP. Bolsista de Produtividade em Pesquisa do CNPq.

E-mail: jlchna@usp.br 